\title{
THE CORRELATION BETWEEN icaA AND icaD GENES WITH BIOFILM FORMATION Staphylococcus epidermidis IN VITRO
}

\author{
Dian Rachmawati ${ }^{1}$, Kuntaman $^{2}$, Lindawati Alimsardjono ${ }^{2}$ \\ ${ }^{1}$ Faculty of Medicine, Universitas Mulawarman, Samarinda, ${ }^{2}$ Department of Medical Microbiology, Faculty of \\ Medicine, Universitas Airlangga, Dr Soetomo Hospital, Surabaya, Indonesia
}

\section{ABSTRACT}

\begin{abstract}
This study was conducted to identify the presence of icaA and icaD genes in S. epidermidis and to analyze the relationship between the presence of icaA and icaD genes with the ability of in vitro biofilm formation in S. epidermidis. S. epidermidis isolates from patients and healthy people were collected and PCR was examined to detect icaA and icaD genes. which then continued to examine the ability of biofilm formation by the method of Congo Red Agar. The results of this genotypic and phenotypic examination were then tested for correlation with statistical tests using SPSS 23.0. A total of 40 S. epidermidis isolates were collected, consisting of 20 clinical isolates and 20 isolates of normal flora. The icaA gene was positive in 5 isolates (12.5\%), and 8 isolates (20\%) were positive for the icaD gene, 3 isolates with icaA and icaD were both positive. One hundred percent of isolates with icaA or icaD positively formed biofilms, but there were 15 isolates (42.9\%) who did not have the icaA gene but showed the ability to form biofilms, while 12 isolates $(37.5 \%)$ who did not have the icaD gene also formed biofilms. Fifty percent of S. epidermidis isolates showed the ability to form biofilms at CRA. The Fisher Exact test showed a significant relationship between the icaA gene and the ability of biofilm formation $(p=0.047(p<0.05))$ as well as the icaD gene $(p=0.03(p<0.05))$. The icaA and icaD genes have a significant relationship to biofilm formation in S. epidermidis. There was another mechanism in the formation of biofilms that are not dependent on the ica gene.
\end{abstract}

Keywords: ica gene; biofilm; Staphylococcus epidermidis

\section{ABSTRAK}

Penelitian ini dilakukan untuk mengidentifikasi keberadaan gen icaA dan icaD pada S. epidermidis serta menganalisis hubungan antara keberadaan gen icaA dan icaD dengan kemampuan pembentukan biofilm in vitro pada S. epidermidis. Isolat S. epidermidis yang berasal dari pasien dan orang sehat dikumpulkan dan dilakukan pemeriksaan PCR untuk mendeteksi gen icaA dan icaD. yang kemudian dilanjutkan pemeriksaan kemampuan pembentukan biofilm dengan metode Congo Red Agar. Hasil pemeriksaan genotif dan fenotif ini selanjutnya diuji hubungan dengan uji statistik menggunakan SPSS 23.0. Sejumlah 40 isolat S. epidermidis terkumpul, terdiri dari 20 isolat klinik dan 20 isolat flora normal. Gen icaA positif pada 5 isolat (12,5\%), dan 8 isolat (20\%) positif gen icaD, 3 isolat dengan icaA dan icaD yang keduanya positif. Seratus persen isolat dengan icaA atau icaD positif membentuk biofilm, namun terdapat 15 isolat (42,9\%) yang tidak memiliki gen icaA tapi menunjukkan kemampuan membentuk biofilm, sementara 12 isolat (37,5\%) yang tidak memiliki gen icaD juga membentuk biofilm. Lima puluh persen isolat S. epidermidis menunjukkan kemampuan membentuk biofilm pada CRA. Uji Fisher's Exact menunjukkan hubungan bermakna antara gen icaA dengan kemampuan pembentukan biofilm $(p=0,047(p<0,05))$ demikian pula dengan gen icaD $(p=0,03(p<0,05))$. Gen icaA dan icaD memiliki hubungan yang bermakna bagi pembentukan biofilm pada S. epidermidis. Terdapat mekanisme lain dalam pembentukan biofilm yang tidak tergantung gen ica.

Kata kunci: Gen ica; biofilm; Staphylococcus epidermidis

Correspondence: Dian Rachmawati, Faculty of Medicine, Universitas Mulawarman, Samarinda, Indonesia. E-mail: ukhti_rachmawati@yahoo.com

pISSN:2355-8393 • eISSN: 2599-056x • doi: http://dx.doi.org/10.20473/fmi.v55i4.17311

- Fol Med Indones. 2019;55:251-259 • Received 8 Aug 2017 • Accepted 22 Feb 2018

- Open access under CC-BY-NC-SA license • Available at https://e-journal.unair.ac.id/FMI/

\section{INTRODUCTION}

Biofilm are structured communities of bacteria, which are attached to the surface and and embedded in a selfproduced matrix of extracellular polymeric substances
(Abee et al 2011, Heilmann et al 1996). Nowadays biofilms become a seriously public health problems because biofilm-associated microorganisms exhibit dramatically decreased susceptibility to antimicrobial agents and their potency to cause medical devices 
indwelling related infection and more resistant to host immune systems (Davey \& O'toole 2000, Donlan 2001). In biomaterial associated infection, almost $80 \%$ of the cells involve Staphylococcus epidermidis. This fact can be explained by the ease access of them as the skin flora then occupied and attached to the wound and implant (von Eiff et al 2002).

S. epidermidis is prototypic bacteria forming biofilm that important cause infection (Mack et al 2013). Biofilm production of Staphylococcus depend on several regulator proteins, however the essential factors are presence and expression of icaADBC operon that encode PIA ( $\mathrm{Li}$ et al 2005).

Molecular study have revealed that attachment stage which the microorganism were adhered each other innitially and were elaborated formed biofilm, mediated PIA that synthesized product of icaADBC operon (Mack et al 1996, Chaieb et al 2005).Trough biofilm mediating ica operon, enabling this bacteria to colonize inert surfaces of medical devices (Zieburh et al 2006).

PIA positive strain can be distinguished from PIA negative strain by Congo Red Agar method (Heilman dan Gotz 1998). PIA positive strains formed black and dry crystal colonies, while PIA negative formed red colonies (Reid 1999, Gotz 2002). Several studies have demonstrated that CRA method are fast, sensitive, reproducible and colony growing in this medium can still be used for further analysis (Freeman et al 1989, Arciola et al 2002, Kaiser et al 2013).

\section{MATERIALS AND METHODS}

\section{Bacterial strains}

A number of 40 isolates of $S$. Epidermidis were obtained from blood specimen of sepsis patients and skin swab of health volunteers, then were identified in Clinical Microbiology Laboratory Dr. Soetomo Hospital Surabaya. DNA isolation and PCR were done in Institute of Tropical Disease Universitas Airlangga.

\section{Rejuvenation of $S$. epidermidis isolates}

Stock isolates were kept in TSB and glycerol 50\% solutions, then were stored in-800C. S. Epidermidis bacteria were re-cultured on Blood Agar medium, incubated at $35 \pm 20^{\circ} \mathrm{C}$ for $18-24$ hours. The pure colony growths on Blood agar plate were picked 3-5 colonies by disposable loop to perform DNA isolation, while biofilm formation were examined by Congo Red Agar method.

\section{DNA extraction with boiling method}

As many as 3-5 colonies were added into200 $\mu \mathrm{l}$ TE solution $\mathrm{pH} 8.0$ in $1.5 \mathrm{ml}$ extraction tube and vortex thoroughly. Briefly, the bacteria suspension were boiled in thermostat at $99^{\circ} \mathrm{C}$ for 10 minutes, then the tube were chilled for 1-3 minutes at room temperature. The suspension were centrifuged at $10.000 \mathrm{~g}$ for 5 minutes. The supernatan obtained was used as DNA template for PCR process.

\section{DNA amplification by PCR}

PCR was performed by Cycler machine (Biorad) to amplify the icaA and icaD genes. The oligonucleotide primer for icaA were,forward 5'-TCT CTT GCA GGA GCA ATC AA-3' and reverse 5'-TCA GGC ACT AAC ATC CAG CA-3' and oligonucleotide primer for icaD were, forward 5'-ATG GTC AAG CCC AGA CAG AG3' and reverse 5'-CGT GTT TTC AAC ATT TAA TGC AA-3' (Arciola et al 2001, El-Mahallawy et al 2009, Terki et al 2013; Zhou et al 2013). Mix PCR for uniplex PCR icaA and icaD consist of $12,5 \mu \mathrm{l}$ Go Taq ${ }^{\circledR}$ Green Master Mix Promega, primers with each volume $1 \mu \mathrm{L}, 5$ $\mu \mathrm{l}$ template DNA and ddH2O until final volume $25 \mu \mathrm{l}$. The PCR cycle was as carried out follows: predenaturation at $94^{\circ} \mathrm{C}$ for $4 \mathrm{~min} ; 40$ cycles of denaturation at $94^{\circ} \mathrm{C}$ for 30 seconds, annealing at $57,6^{\circ} \mathrm{C}$ for 30 seconds, and extension at $72^{\circ} \mathrm{C}$ for 30 seconds; and a final extension step at $72^{\circ} \mathrm{C}$ for 10 min. The amplicon was electrophoresed into $3 \%$ agarose gel, stained with Ethidium bromid. S. epidermidis ATCC 35984 is used as positive quality control (slimeproducing strain) and S. epidermidis ATCC 12228 as negative control (non-slime-producing strain) (Li et al 2009).

\section{Biofilm formation examination}

Biofilm formation were examined by Congo Red Agar (CRA) method. This medium was prepared by adding 0,8 gCongo Red (Sigma-Aldrich, Steinheim, Germany), $10 \mathrm{~g}$ Bacto agar (Becton, Dickinson and Co, Sparks, MD, USA), $37 \mathrm{~g}$ BHI (Oxoid, Basingstoke, UK) and 50 g Suchrose (Merck, Darmstadt, Germany) to $1.000 \mathrm{~mL}$ Aquades. S. epidermidis were cultured on Blood Agar Plate (BAP) and were incubated at $35^{\circ} \mathrm{C}$ during $18-24$ h. Bacteria suspension were prepared by $0,85 \%$ sterilized $\mathrm{NaCl}$ with $1,5 \times 108 \mathrm{CFU} / \mathrm{mL}$ (0,5 Mc Farland Standard). A 4- $\mu \mathrm{L}$ aliquot of a bacterial suspension was inoculated in a spot and incubated at $35^{\circ} \mathrm{C}$ under aerobic conditions for $24 \mathrm{~h}$. Ten strains were inoculated per plate. The results were checked by 3 observers, and the experiments with CRA were performed at least twice. The colonies of bacteria on Congo Red Agar were evaluated by the criteria as follows: 1+: dark red 
colonies, non biofilm producer, $2+$ : red colonies, non biofilm producer, $3+$ : brown colonies, biofilm producer, $4+$ : black colonies, biofilm producer (Christensen et al 1982, Arciola et al 2005, Kaiser et al 2013).

\section{RESULTS}

Forty isolates of $S$. epidermidis were checked the presence of icaA and icaD genes consist of 20 clinical isolates and 20 normal flora isolates. PCR revealed the presence of of icaA and icaD genes in S. epidermidis (Figs. 1 and 2).
Electrophoresed results showed 5 (12.5\%) icaA positive isolates, $8(20 \%)$ icaD positive isolates, $3(7.7 \%)$ isolates with both of icaA and icaD positive genes and $30(75 \%)$ isolates with icaA and icaD were negative (Table 1). All of the ica positive genes were clinical isolates.

The biofilm producing phenotype of $S$. epidermidis were determined on CRA (Fig. 3). Fig. 5 shows the percentage of icaA gene related biofilm forming examination on CRA. All of the icaA positive isolates formed biofilm, while $42,9 \%$ of icaA negative isolates formed biofilm and $57,1 \%$ of them not formed biofilm.

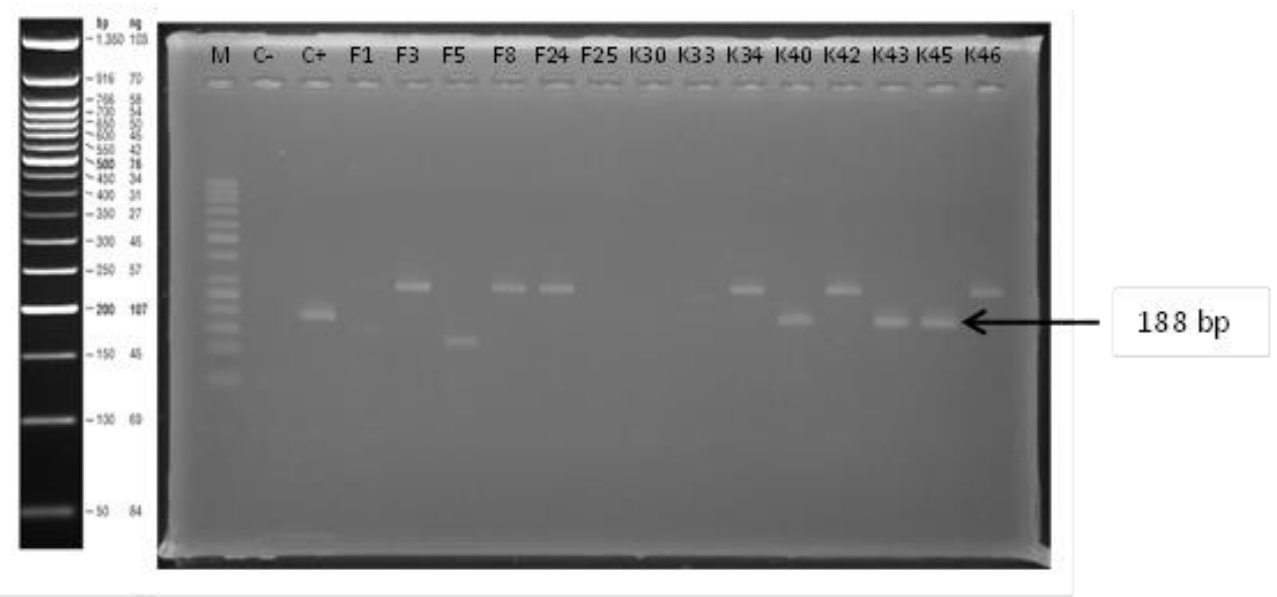

Fig. 1. PCR detection of icaA from S. epidermidis isolates were shown by amplicon of 188 bp; Lane $1(\mathrm{M})=\mathrm{Marker}$ (Marker gene ruler 50 bp DNA ladder (INTRON Sizer 50 plus DNA marker), Lane 2 (C -) = negative control, Lane $3(\mathrm{C}+)$ = icaA from control isolate (S. epidermidis ATCC 35984), Lane 4-14 = sample number.

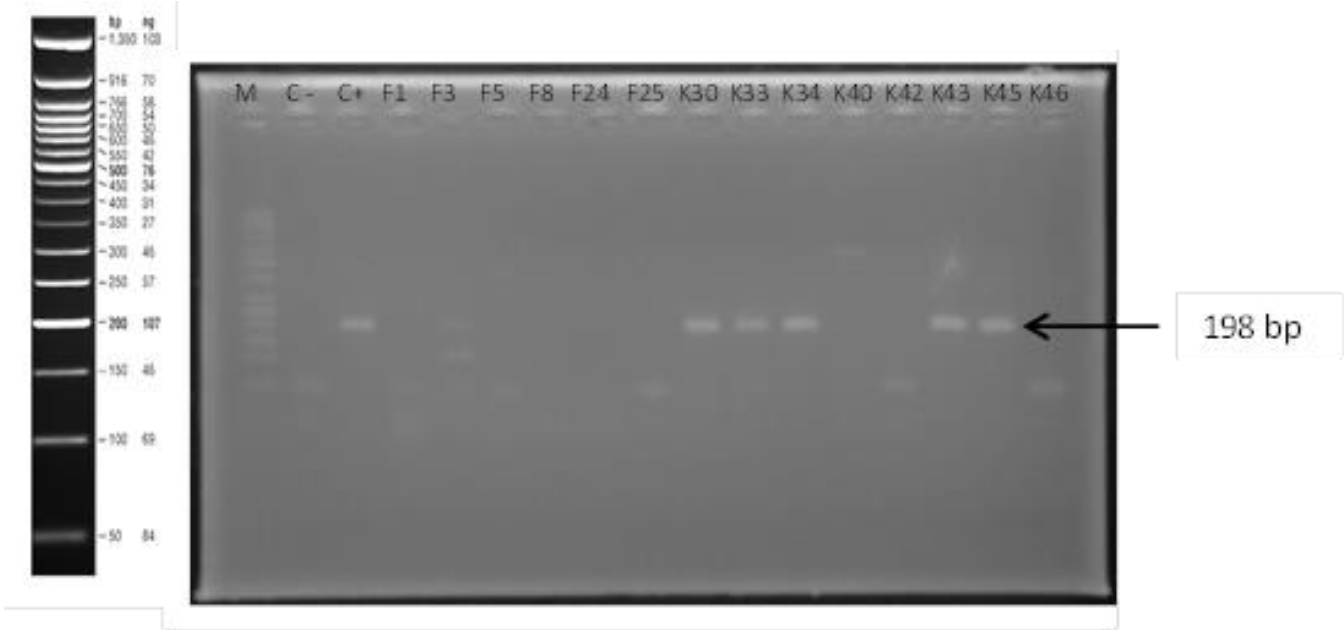

Fig. 2. PCR detection of icaD from S. epidermidis isolates were shown by amplicon of 198 bp; Lane $1(\mathrm{M})=\mathrm{Marker}$ (Marker gene ruler 50 bp DNA ladder (INTRON Sizer 50 plus DNA marker), Lane 2 (C-) = negative control, Lane $3(\mathrm{C}+)=$ icaA from control isolate (S. epidermidis ATCC 35984), Lane 4-14 = sample number. 
Table 1. icaA and icaD genes detection results from S. epidermidis isolates

\begin{tabular}{lcccccc}
\hline \multicolumn{1}{c}{$i c a A$} & \multicolumn{2}{c}{ Positive } & \multicolumn{2}{c}{ Negative } & \multicolumn{2}{c}{ Total } \\
icaD & & & & & & \\
\hline Positive & 3 & $7.5 \%$ & 5 & $12.5 \%$ & 8 & $20 \%$ \\
Negative & 2 & $5 \%$ & 30 & $75 \%$ & 32 & $80 \%$ \\
\hline Total & 5 & $12.5 \%$ & 35 & $87.5 \%$ & 40 & $100 \%$ \\
\hline
\end{tabular}

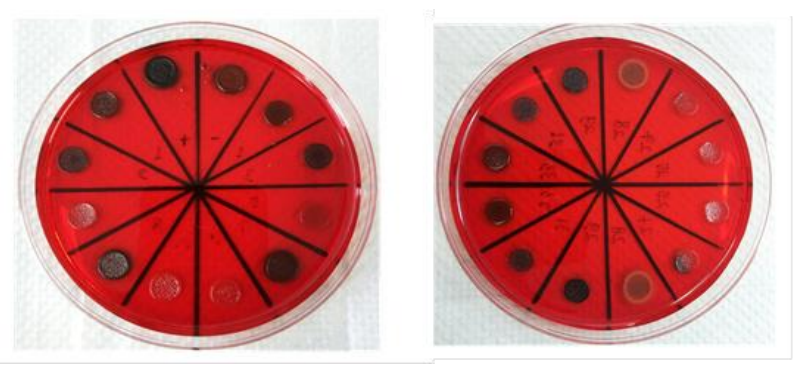

Fig. 3. Biofilm forming examination results with CRA method. Black and brown colonies indicating biofilm producer strains. while red and dark red colonies indicating non biofilm producer strains.
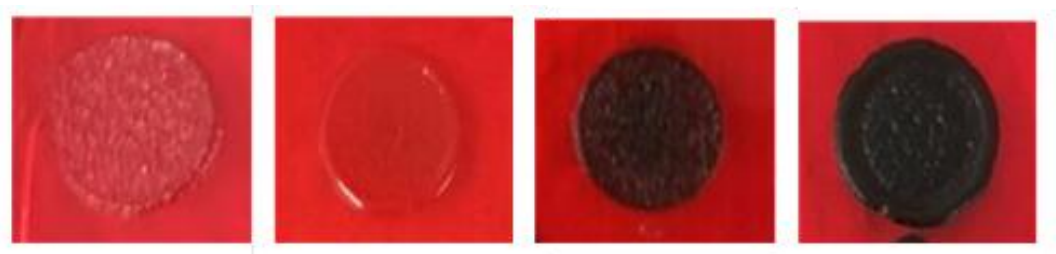

Fig. 4. Colony colors on CRA with spot inoculation: A. Dark red; B. Red; C. Brown; D. Black.

One hundred percent of icaD positive isolates formed biofilm, while $37.5 \%$ of icaD negative isolates formed biofilm tooand $62.5 \%$ of them were not formed biofilm. Biofilm forming examination results by Congo red agar method were shown $50 \%$ of S. epidermidis isolates were biofilm producer.

\section{DISCUSSION}

Genetic and molecular basics of biofilm formation $S$. epidermidis quite variable. Biofilm in S. epidermidis can be formed by means of several mechanism, but biofilm formation which were mediated by polysaccharide adhesin (PSA) capsule and polysaccharide intracellular adhesin (PIA) or polymeric $\mathrm{N}$-acetyl-glucosamine (PNAG) production were one of the most important and now understood as one of the basic mechanisms of biofilm formation associated infection (Beenken et al 2003, Stanley \& Lazazzera 2004, Yazdani et al 2006, O'Gara 2007). PIA synthesis involves complex processes and is influenced by various factors, such as the constitutional factors of microbes, environmental factors and the host clinical situation (Agarwal \& Jain 2011).

This study showed that $40 \mathrm{~S}$. epidermidis isolates were examined, $5(12.5 \%)$ were icaA positive gene and 8 (20\%) were icaD positive gene, while $3(7.7 \%)$ with both of icaA and icaD positive genes. This data are somewhat different with Pinheiro et al (2014) which showed the presence one of ica gene were detected in $89.7 \%$ isolates, the complete of ica genes were detected in $38,3 \%$ isolates, while $43.9 \%$ isolates were harbored icaA and icaD genes. In this study, the isolates were not all of them originated from clinical isolates that cause infection, then ica gene were not frequent.

Zhou et al. study (2013) revealed though icaA and icaD genes often overlap and cotranscription. The icaD has a higher positive detection than icaA, icaB and icaC. There were possible occured because lose and mutated of these genes. This study demonstrated icaD positive gene more frequent ( 8 isolates) than icaA positive gene (5 isolates). 


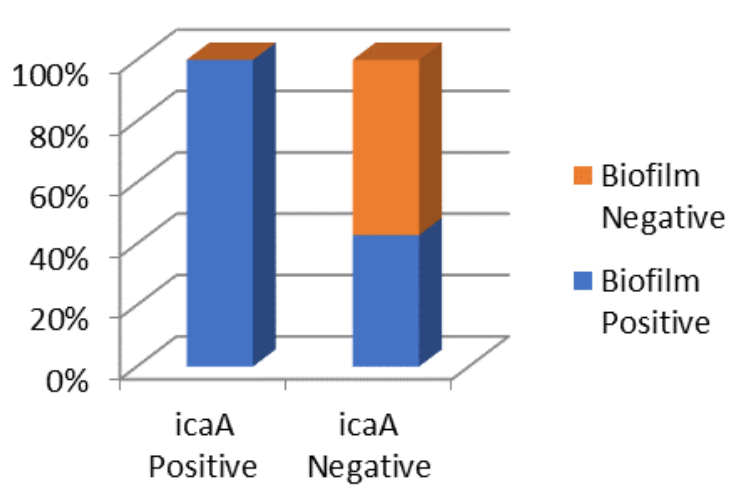

Fig. 5 The Percentage of icaA gene related biofilm forming capacity on CRA.

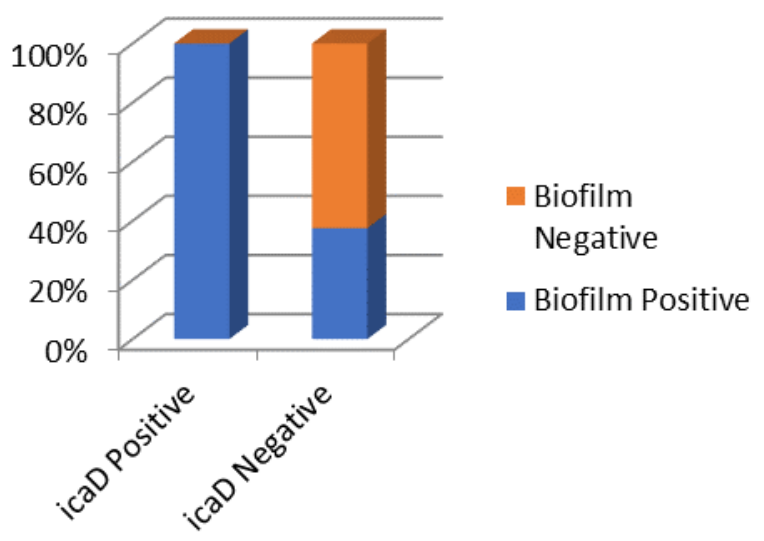

Fig. 6. The Percentage of icaD gene related biofilm forming capacity on CRA.

Biofilm which were detected trough CRA method in this study were 20 isolates $(50 \%)$. This results are similar with Satorres dan Alcara'z study (2007) that showed $41.3 \%$ of staphylococci were biofilm producer. Nasr et al study (2012) demonstrated biofilm forming examination with CRA method, and showed that $46 \%$ of staphylococcus isolates were detected as biofilm producer. Foka et al (2006) and Arslan et al (2007) in their study revealed in which the percentage of slimeproducing strains of S. epidermidis ranged from $31 \%$ to $89 \%$.

All of the isolates which icaA gene conceived have biofilm forming capacity on the CRA ( 1 isolate formed brown colony and 4 isolates formed black colonies), as well as the icaD gene positive isolates, all over also have biofilm forming capacity ( 2 isolates formed brown colonies and 6 colonies formed black colonies), while ica negative strains have variable colonies, there were red, dark red, brown and black.
The results of this sudy are similar with Los et al study (2010) revealed that most of ica-positive S. epidermidis showed biofilm forming capacity with CRA method. Similar data were desmonstated by several previous studies (Arciola et al 2002, El-Mahallawy et al 2009, Mariana et al 2009, Zhou et al 2013, Kaiser et al 2013). The results of these studies have shown the presence of ica gene was strong related with biofilm phenotype.

In this study, 15 of $35(42.9 \%)$ isolates without icaA and 12 of $32(37.5 \%)$ isolates without icaD can be formed biofilm on the CRA. Similar with Duggirala et al. study (2007) which that strain showed biofilm formation by CRA, some of them did not have ica genes. Nasr et al (2012) also demonstrated that $36 \%$ icaAD negative strain, capable to produce biofilm on the CRA, while Arciola et al (2006) found this phenomenon in $16 \% \mathrm{~S}$. epidermidis isolate.

Oliviera and Cunha (2010) in their study revealed there are biofilm production in ica negative strain. This results indicated biofilm formation were complex network of several factors and ica genes not just the one of regulator that biofilm formation. Meaning eventhouh does not have ica gene, this bacteria still form biofilm through other mechanism. Beside ica genes independent mechanism, there are others mechanism which are possible that owned by S. epidermidis to form of biofilm on the CRA.

Mechanism that involved in regulation of locus ica transcription only part of it has been understood and still other different regulated mechanism which is known (Arciola et al 2012). Staphylococcus produce exopolysaccharide Polysaccharide Intercellular Adhesin (PIA) or Polymeric N-Acetyl-Glucosamine (PNAG) is synthetized and excreted by protein are encoded icaADBC genes, but in vitro there are ica independent biofilm production (O’ gara et al 2007).

In a study have proved PNAG/PIA not always absolutely necessary for $S$. epidermidis biofilm formation, and its may occure in biofilms formations with lack of ica and ica-negative genes are isolated from biofilm related infections. In many strain, biofilm formation can be mediated by specific surface proteins, called by Bap/Bhp (Biofilm associated protein) and Aap (Accumulation associated protein) and a number of Extracellular Teichoic Acids (ECTA), all of which are involved in the ica-independent biofilm formation mechanism, which is also under the control of the sarA regulator gene (Ziebuhr 2006, Otto 2008).

Other mechanism of ica-independent biofilm formation were demonstrated by O'Gara (2007), that atl gene have 
an important role in initially adherence stage of biofilm developing. The alternative mechanism of biofilm synthesis relies on the ability of $S$. epidermidis to express a variety of adhesin proteins that allow cells to attach and colonize a number of different surfaces. These bacteria can also form biofilm using proteins (eDNAs) even though they do not produce polysaccharides.

Statistical analysis in this study indicate that there is a relationship between the presence of icaA and icaD genes with the biofilm forming capacity. The icaD gene (coefficient association of phi $=0.5$ ) has a stronger relationship when compared with the icaA gene (coefficient association of phi $=0.37$ ) to the biofilm formation on CRA. Based on statistical analysis, when icaA and icaD coincide in one bacteria, the strength of its relationship with biofilm forming capacity is increasing (coefficient association of phi $=0.577$ ), this corresponds to a study by McCann et al (2008) and Otto (2008) who stated that the simultaneous expression of icaA and icaD genes were shown to increase $\mathrm{N}$ acetylglucosamine transferase. It is likely that the icaA protein requires icaD to translate an active conformation (Mack et al 1999, Otto, 2008).

PIA is synthesized from UDP-N-acetylglucosamine by $\mathrm{N}$-acetylglucosaminyltransferase, which is encoded by ica loci, especially icaA. The single expression by this gene induces a low enzymatic activity resulting in the production of polysaccharide as well. The simultaneous expression of icaA and icaD would significantly increase $\mathrm{N}$-acetylglucosaminyltransferase, and consequently an increase in the number of polysaccharide, forming a 10-20 ß-1.6-Nacetylglucosamine oligomeric residue (Dobinski et al 2002, Gotz 2002).

Researchof Zhou et al (2013) showed similar results with this study, that there is a stronger relationship between the presence of both the icaA and icaD genes and biofilms forming capacity compared to single expression icaA or icaD alone. Cafiso (2004) suggests that the overall existence of genes is not necessarily related to biofilm production, but there is an indication that there appears to be a correlation that can occur when at least two genes (icaAD) undergo co-transcription.

In contrast to the ica negative bacteria but its able to form biofilms that were found in some isolates in this study, there is sometimes a phenomenon in which ica is present, but the biofilm phenotype is negative, as described by Cafiso (2004) in a study that found that although the icaA or icaD genes was found $S$. epidermidis, nor can biofilms form. The reason for not producing biofilms in some isolates is that although there are all ica genes, the icaC gene being considered necessary for PIA elongation is lack of transcription, although this is unclear.

The product of the icaR gene, together with changes in environmental conditions, may affect the expression of the ica genes (Cafiso 2004). Although staphylococci indicates the presence of ica genes, the expression of ica and biofilm production are strictly dependent on environmental conditions associated with gene expression involved adhesion process (Rachid et al 2000, Toledo Arana et al 2005, O'Gara 2007). Some environmental signals such as $\mathrm{CO} 2, \mathrm{O} 2$, iron limitations, antibiotic exposure, anaerobic conditions, ethanol, glucose levels, and osmotic stress (high osmolarity) may alter the regulation of ica expression and biofilm formation (Rachid et al 2000, Yazdani et al 2006, Otto 2008). Other factors affecting biofilm formation vary widely, such as humidity, temperature, $\mathrm{pH}$ of the environment, weather conditions, and chemical composition of the substrate nutrition (Kaali et al 2011).

The presence of the icaA and icaD genes are not always correlated with biofilm formation in vitro. The forming capacity in some isolates are also shared by strains lacking the icaA and icaD genes, so further investigation of genetic and biofilm-forming mechanisms independent of ica is still needed (Nasr et al 2012).

S. epidermidis has the potential ability to form biofilms with either ica-dependent and/or ica-independent mechanisms (Los 2010). Early detection and handling of biofilm formation of staphylococci are important step for the prevention and treatment of device-associated nosocomial infections, thus requiring simple phenotypic evaluation for the detection of biofilm producers (Jain \& Agarwal 2009).

Moretro et al (2003) suggests that it is more appropriate to use biofilm formation methods and whether present or without locus ica is one of the criteria for determining potentially virulent strains, since biofilm formation on inert surfaces is highly sensitive to environmental and nutritional conditions, such as the presence of ethanol, iron, various concentrations of glucose and $\mathrm{NaCl}$.

The combination of phenotypic and genotypic methods allow screening of strains that are potentially able to express the genes of biofilm formation of the Staphylococcus. Further study of regulatory mechanisms of biofilm formation by Staphylococcus in environmental processes, especially the genetic variation between strains is still needed (Ferreira et al 2014). 


\section{CONCLUSION}

icaA and icaD genes have a statistically significant correlation with regards to biofilm formation in $S$. epidermidis. There are others biofilm formation mechanism that ica independent

\section{ACKNOWLEDGMENT}

I would like thank to all staff in Clinical Microbiology Laboratory in Dr. Soetomo Hospital Surabaya and Institute Tropical Diseases, Universitas Airlangga, especially Wahyu Setyarini S. Si and Radita Yuniar Arizandy, S. Si who have assisted during the research process at the laboratory.

\section{REFERENCES}

Abee T, Kovacs A, Kuipers OP, van der Veen S (2011). Biofilm formation and dispersal in gram-positive bacteria. Current Opinion in Biotechnology 22, 172179

Agarwal A, Jain A (2013). Glucose \& sodium chloride induced biofilm production \& ica operon in clinical isolates of staphylococci. The Indian Journal of Medical Research 138, 262-266

Arciola CR, Baldassarri L, Montanaro L (2001). Presence of icaA and icaD genes and slime production in a collection of Staphylococcal strains from catheterassociated infections. J Clin Microbiol 39, 2151-6

Arslan S, Ozkardes F (2007). Slime production and antibiotic susceptibility in Staphylococci isolated from clinical samples. Memorias do Instituto Oswaldo Cruz 102, 29-33

Beenken KE, Blevins JS and Smeltzer MS (2003). Mutation of sarA in Staphylococcus aureus limits biofilm formation. Infection and Immunity 71, 42064211

Cafiso V, Bertuccio T, Santagati M, Campanile F, Amicosante G, Perilli MG, Selan L, Artini M, Nicoletti G, Stefani S (2004). Presence of the ica operon in clinical isolates of Staphylococcus epidermidis and its role in Biofilm Production. Clin Microbiol Infect 10, 1081-1088

Cerca N, Pier GB, Vilanova M, Oliveira R, Azeredo J (2004). Influence of batch or fed-batch growth on Staphylococcus epidermidis biofilm formation. Lett Appl Microbiol 39, 420-4

Chaieb K, Mahdouani K, Bakhrouf A (2005). Detection of icaA and icaD loci by polymerase chain reaction and biofilm formation by Staphylococcus epidermidis isolated from dialysate and needles in a dialysis unit. JHosp Infect 61, 225-30
Christensen GD, Simpson WA, Bisno AL, Beachey EH, 1982. Adherence of slime-producing strains of Staphylococcus epidermidis to smooth surfaces. Infect Immun 37: 318-26.

Davey ME, O'otole GA, 2000. Microbial Biofilms: from Ecology to Molecular Genetics. Microbiol Mol Biol Rev 64: 847-867.

Dobinski S, Bartscht K, Mack D, 2002. Influence of Tn917 insertion of transcription of the icaADBC operon in six biofilm-negative transposon mutants of Staphylococcus epidermidis. Plasmid 47:10-17.

Donlan RM, 2001. Biofilm Formation: A Clinically Relevant Microbiological Process.Clinical Infectious Diseases 33:1387-92.

Donlan RM, 2001. Biofilms and Device-Associated Infections. Emerging Infectious Diseases 7: 277-81.

Duggirala A, Kenchappa P, Sharma S, et al ., 2007. High-resolution genome profiling differentiated Staphylococcus epidermidis isolated from patients with ocular infections and normal individuals. Invest Ophthalmol Vis Sci 48:3239-3245.

El-Mahallawy HA, Loutfy SA, El-Wakil M, Abd El-Al $\mathrm{AK}$ and Morcos H, 2009. Clinical Implications of icaA and icaD Genes in Coagulase Negative Staphylococci and Staphylococcus aureus Bacteremia in Febrile Neutropenic Pediatric Cancer Patients. Pediatr Blood Cancer 52: 824-828

Ferreira AA, Tette PAS, Mendonca RCAS, Soares AS, de Carvalho MM, 2014. Detection of exopolysaccharide production and biofilm-related genes in Staphylococcus spp. isolated from a poultry processing plant. Food Sci. Technol 34: 710-716.

Foka A, Chini V, Petinaki E, Kolonitsiou F, Anastassiou ED, Dimitracopoulos G,

Spiliopoulou I, 2006. Clonality of Slime-Producing Methicillin-Resistant Coagulase-Negative Staphylococci Disseminated in The Neonatal Intensive Care Unit of A University Hospital. Clin Microbiol Infect 12: 1230-1233.

Freeman J, Falkiner FR, Keane CT, 1989. New Method for Detecting Slime Production by Coagulase Negative Staphylococci. J Clin Pathol 42: 872-4.

Gotz F, 2002. Staphylococcus and Biofilms. Mol Microbiol 43: 1367-1378.

Heilmann C, Schweitzer O, Gerke C, Vanittanakom N, Mack D, Gotz F, 1996. Molecular Basis of Intercellular Adhesion in The Biofilm-Forming Staphylococcus epidermidis. Mol Microbiol 20:108391.

Heilmann C, Gotz F, 1998. Further characterization of Staphylococcus epidermidis transposon mutants deficient in primary attachment or intercellular adhesion. Zentralbl Bakteriol 287: 69-83.

Jain A, Agarwal A, 2009. Biofilm Production, a Marker of Pathogenic Potential of Colonizing and Commensal Staphylococci. J Microbiol Methods 76: 88-92. 
Kaali P, Strömberg E and Karlsson S, 2011. Prevention of Biofilm Associated Infections and Degradation of Polymeric Materials used in Biomedical Applications. Biomedical Engineering, Trends in Materials Science, Mr Anthony Laskovski (Ed.), ISBN: 978-953-307513-6, InTech.

Kaiser TDL, Pereira EM , dos Santos KRN, Maciel ELN, Chuenck RP, Nunes APF, 2013. Modification of the Congo Red Agar Method to Detect Biofilm Production by Staphylococcus epidermidis. Diagnostic Microbiology and Infectious Disease 75: 235-239

Li H, Xu L, Wang J, Wen Y, Vuong C, Otto M, Gao Q, 2005. Conversion of Staphylococcus epidermidis Strains from Commensal to Invasive by Expression of the ica Locus Encoding Production of Biofilm Exopolysaccharide Hualin. Infection and Immunity 73:3188-3191.

Los R, Sawicki R, Juda M, Stankevic M , Rybojad P, Sawicki M, Malm A \& Ginalska G, 2010. A comparative analysis of phenotypic and genotypic methods for the determination of the biofilm-forming abilities of Staphylococcus epidermidis . FEMS Microbiol Lett 310: 97-103.

Madigan MT, Martinko JM, Brock TD, 2006. Brock Biology of Microorganisms. 11th Ed. New Jersey: Pearson Prentice Hall: 617-619.

Mack D, Davies A P, Harris L G, Jeeves R , Pascoe B , Knobloch J K M , Rohde H , and Wilkinson T S. Moriarty T.F.et al, 2013. Staphylococcus epidermidis in Biomaterial-Associated Infections, Biomaterials Associated Infection: Immunological Aspects 25.

Mack D, Fischer T L ,Krokotsch A, Leopold K, Hartmann R, Egge H et al ., 1996. The intercellular adhesion involved in biofilm accumulation of Staphylococcus epidermidis is a linear1,6linkedglucosaminoglycan: purification and structur alanalysis. J Bacteriol 178: 175-83.

Mariana NS, Salman SA, Neela V, Zamberi S, 2009. Evaluation of Modified Congo Red Agar for Detection of Biofilm Produced by Clinical Isolates of Methicillin- Resistance Staphylococcus aureus. African Journal of Microbiology Research 3: 330-338.

McCann MT, Gilmore BF, Gorman SP, 2008. Staphylococcus epidermidis device-related infections: pathogenesis and clinical management. J Pharm Pharmacol 60: 1551-1571

Moretro T, Hermansen L, Holck AL, Sidhu MS, Rudi K \& Langsrud S, 2003. Biofilm formation and the presence of the intercellular adhesion locus ica among staphylococci from food and food processing environments. Applied and Environmental Microbiology 69: 5648-5655.

Nasr RA, AbuShady HM, Hussein HS, 2012. Biofilm formation and presence of icaAD gene in clinical isolates of staphylococci. The Egyptian Journal of Medical Human Genetics 13: 269-274.
O'Gara JP, 2007. ica and Beyond: Biomechanisms and Regulation in Staphylococcus epidermidis and Staphylococcus aureus. FEMS Microbiol Lett 270: 179-188.

Oliveira A and Cunha M, 2010. Comparison of methods for the detection of biofilm production in coagulasenegative staphylococci. BMC Research Notes 3:260.

Otto, 2008. Staphylococcal Biofilms. Curr Top Microbiol Immunol 322: 207-228.

Otto M, 2009. Staphylococcus epidermidis - the "Accidental" Pathogen. Nat Rev Microbiol 7: 555567.

Pinheiro L, Brito CI, Pereira VC, de Oliveira A, Camargo CH, de Lourdes M, and da Cunha R, 2014. Reduced susceptibility to vancomycin and biofilm formation in methicillin-resistant Staphylococcus epidermidis isolated from blood cultures. Mem Inst Oswaldo Cruz 109: 871-8.

Rachid S, Ohlsen K, Witte W, Hacker J, Ziebuhr W, 2000. Effect of subinhibitory antibiotic concentrations on polysaccharide intercellular adhesin expression in biofilm-forming Staphylococcus epidermidis. Antimicrob Agents Chemother 44: 3357-63.

Reid G, 1999. Biofilms in infectious disease and on medical devices. Int. J. Antimic 11: 223-6.

Satorres SE, Alcara'z LE, 200. Prevalence of icaA and icaD genes in Staphylococcus aureus and Staphylococcus epidermidis strains isolated from patients and hospital staff. Cent Eur J Public Health 15: 87-90.

Stanley NR \& Lazazzera BA, 2004. Environmental signals and regulatory pathways that influence biofilm formation. Molecular Microbiology 52: 917-924.

Terki IK, Hassaine H, Oufrid S, Bellifa S, Mhamedi I, Lachachi M, Timinouni M, 2013. Detection of icaA and icaD genes and Biofilm Formation in Staphylococcus spp. Isolated from Urinary Catheters at The University Hospital of Tlemcen (Algeria). African Journal of Microbiology Research 7: 53505357.

Toledo-Arana A, Merino N, Vergara-Irigaray M., Débarbouillé M, Penadés JR \& Lasa I, 2005. Staphylococcus aureus develops an alternative, icaindependent biofilm in the absence of the arlRS twocomponent system. Journal of Bacteriology 187: 5318-5329.

Von Eiff C, Peters G, Heilmann C, 2002. Pathogenesis of Infections Due to Coagulase-Negative Staphylococci. Lancet Infect Dis 2: 677-685.

Yazdani R, Oshaghi M, Havayi A, Pishva E, Salehi R, Sadeghizadeh M \& Foroohesh, H, 2006. Detection of icaAD gene and biofilm formation in Staphylococcus aureus isolates from wound infections. Iranian Journal of Public Health 35: 25-28.

Zhou S, Chao X, Fei M, Dai Y and Liu B. 2013. Analysis of $S$. epidermidis icaA and icaD genes by 
Polymerase Chain Reaction and Slime Production: A Case Control Study. BMC Infectious Diseases 13:242. Ziebuhr W, Hennig S, Eckart M, Kranzler H, Batzilla C, Kozitskaya, 2006. Nosocomial Infections by
Staphylococcus epidermidis: How A Commensal Bacterium Turns into A Pathogen. International Journal of Antimicrobial Agents 28S: S14-S20. 